\title{
Integrating maize and triticale in grass/clover based dairy systems: examining yields and autumn soil nitrate levels
}

\author{
J.B. PINXTERHUIS ${ }^{1}$, H.C. DE BOER ${ }^{2}$, N.J.M. VAN EEKEREN ${ }^{3}$ and M.W.J. STIENEZEN ${ }^{2}$ \\ ${ }^{1}$ DairyNZ, PO Box 85066, Lincoln University 7647, New Zealand \\ ${ }^{2}$ Wageningen UR Livestock Research, PO Box 65, 8200 AB Lelystad, The Netherlands \\ ${ }^{3}$ Louis Bolk Institute, Hoofdstraat 24, 3972 LA Driebergen, The Netherlands
}

Ina.Pinxterhuis@DairyNZ.co.nz

\begin{abstract}
To establish $\mathrm{N}$-efficient crop rotations with perennial ryegrass/white clover, maize and triticale, a 9-year field experiment was executed on an organic experimental farm in the Netherlands. Crop rotations with different levels of slurry (dairy effluent from the free-stall barn, average dry matter content of 7\%) application were tested for dry matter (DM) yield, $\mathrm{N}$ yield, soil mineral $\mathrm{N}$ in autumn, soil organic matter and soil organic $\mathrm{N}$. Maize cropping and slurry application both increased annual DM yield. However, the second year of grass/ clover following maize, maize itself and slurry applications each resulted in higher soil mineral $\mathrm{N}$ in autumn, increasing the risk of nitrate leaching losses. A rotation of 4 years of grass/clover, 2 years of maize and 1 year of triticale resulted in relatively high average annual DM production (12 t DM/ha/year) for Dutch conditions, with a higher potential $\mathrm{N}$ leaching loss in 2 out of 7 years.
\end{abstract}

Keywords: crop rotation, grass clover, maize, triticale, $\mathrm{N}$ efficiency, soil mineral $\mathrm{N}$

\section{Introduction}

Urinary nitrogen $(\mathrm{N})$ excretion is seen as the largest contributor to nitrate leaching in pastoral dairy farming (Di \& Cameron 2002). Feeding supplements with a lower $\mathrm{N}$ content than grass/clover reduces nitrogen $(\mathrm{N})$ intake by grazing dairy cows and reduces urinary $\mathrm{N}$ excretion, but growing these supplements in pastoral systems often increases $\mathrm{N}$ leaching per hectare compared to permanent pasture (Williams et al. 2007). When pasture is cultivated to establish a crop, the mineralising sward adds to the soil mineral N pool (Silgram \& Shepherd 1999) which is prone to $\mathrm{N}$ leaching when drainage occurs. An example for sandy soils in northwest Germany is given by Kayser et al. (2008): permanent pasture $+160 \mathrm{~kg} \mathrm{~N}$ fertiliser/ ha/year resulted on average in $26 \mathrm{~kg}$ mineral $\mathrm{N} / \mathrm{ha}$ in autumn and $8 \mathrm{~kg} \mathrm{NO}_{3}-\mathrm{N} /$ ha leached. Spring cultivation of pasture that received $120 \mathrm{~kg} \mathrm{~N} / \mathrm{ha}$ and was $>15$ years old and growing one season of an unfertilised maize crop, resulted in $113 \mathrm{~kg}$ mineral $\mathrm{N} / \mathrm{ha}$ in autumn and $118 \mathrm{~kg} \mathrm{NO}_{3}-\mathrm{N} /$ ha leached.
To investigate the $\mathrm{N}$ efficiency and dry matter (DM) production of crop rotations involving grass/clover, maize and winter triticale, a 9-year field experiment was carried out in The Netherlands (De Boer et al. 2012). The effects of the number of years in grass/clover and 1 or 2 years of maize cropping were measured. Furthermore, different strategies for slurry application were examined. By limiting the $\mathrm{N}$ input to a maximum of $120 \mathrm{~kg} \mathrm{~N} / \mathrm{ha} /$ year from slurry only (no grazing and no fertiliser $\mathrm{N}$ ), considerable $\mathrm{N}$ fixation by clover could be expected. Soil organic matter, soil organic $\mathrm{N}$ and soil mineral $\mathrm{N}$ were monitored to establish if this $\mathrm{N}$ input was sufficient to maintain soil fertility.

\section{Methods}

A replicated $(\mathrm{n}=3)$ randomised block experiment was carried out from 2002 to 2010 at the organic experimental farm Aver Heino (Heino, The Netherlands). One replicate was situated on an elevated Plaggic Anthrosol, with an A-horizon of 80 to $100 \mathrm{~cm}$ (organic matter content at the start of the experiment of $6.0 \%$ ). The other two replicates were situated on a humus rich, hydromorphic, sandy soil, with one replicate on a coarser sand than the other. The organic matter content of these soils was $4.7 \%$ at the start of the experiment. Other soil fertility parameters were similar for the three replicates, with with PAL (phosphate in ammonium lactate-acetic acid extracts of soils, a measure of plant available phosphate) on average 45 $m g \mathrm{P}_{2} \mathrm{O}_{5} / 100 \mathrm{~g}$ dry soil (i.e., more than sufficient, but not high), P-total $144 \mathrm{mg} \mathrm{P}_{2} \mathrm{O}_{5} / 100 \mathrm{~g}$ dry soil, and $\mathrm{N}$-total $2.52 \mathrm{~g} / \mathrm{kg}$ dry soil.

The treatments consisted of all combinations of six crop rotation schemes and four slurry application strategies (Table 1). Existing perennial ryegrass (Lolium perenne) /white clover (Trifolium repens) pasture was ploughed to establish the plots. Individual plots were $15 \times 6 \mathrm{~m}$. To reduce the likelihood of confounding the effects of crop rotation with weather conditions in any year, and to reduce the effects of the original pasture, the starting year selected for the first replication was year 4 of the crop rotation scheme, for the second replication year 5 and for the third replication year 6 . 
Maize was sown at 9-10 plants $/ \mathrm{m}^{2}$ following harvest and cultivation of grass/clover (first-year maize) or cultivation of a green manure crop (second-year maize). The first triticale plots were sown in autumn 2001 after cultivating and ploughing the existing grass/clover. From 2002 onwards, triticale was always sown after the maize harvest. Triticale was sown at 150 to $200 \mathrm{~kg}$ seed/ha.

No chemical weed or pest control was used during the experiment. Most of the weeds in pasture (mainly Stellaria media and Taraxacum officinale) were removed with the first harvest. Weeds in maize and triticale (notably Echinochloa crus-galli) were controlled with mechanical methods. Plots sown with maize experienced predation from pigeons on the seeds and seedlings, especially from 2005 onwards. Maize plants also suffered feeding damage caused by larvae of the click beetle (Agriotes obscurus). In both instances plants lost were re-sown where possible.

Slurry was sampled each year for analysis of chemical composition, and applied to the applicable plots at a rate of $120 \mathrm{~kg} \mathrm{~N} / \mathrm{ha}$ (Table 1). The average composition of the slurry was $7.1 \% \mathrm{DM}$, organic matter $53 \mathrm{~g} / \mathrm{kg}$ product, $\mathrm{N}$-total $3.3 \mathrm{~g} / \mathrm{kg}$ and $\mathrm{P}_{2} \mathrm{O}_{5} 1.2 \mathrm{~g} / \mathrm{kg}$. A sward injector was used on grass/clover and an injector on maize and triticale. On the grass/clover and triticale plots, slurry was applied as soon as the soils were dry enough to allow machinery on in early spring. Firstyear maize was grown following harvest and cultivation of grass/clover in spring; the slurry was applied on the grass/clover in early spring. For second-year maize, slurry was applied just before sowing, after cultivation of the green manure crop.

All treatments received $\mathrm{P}$ and $\mathrm{K}$ fertiliser in surplus of the annual $\mathrm{P}$ and $\mathrm{K}$ uptake by the crops, taking approximately $40 \mathrm{~kg} \mathrm{P}_{2} \mathrm{O}_{5}$ and $180 \mathrm{~kg} \mathrm{~K} 2 \mathrm{O} /$ ha/year from slurry into account where this was applied. Soil $\mathrm{pH}-\mathrm{KCl}$ was on average 4.7 in 2004 and 5.2 in 2008. Lime was applied to all plots in the autumns of $2005(1400 \mathrm{~kg} / \mathrm{ha}$ Dologran 15 (54\% CaO), 2006 (1200 kg/ha) and 2009 (1400 kg/ha).

Every second year, starting from 2002, soil organic matter content and soil organic $\mathrm{N}$ content of each plot were assessed by taking six random soil cores per plot each spring and in autumn 2010 when the experiment was terminated. Each year, soil cores were taken from each plot in autumn (once maize was harvested) to determine soil mineral $\mathrm{N}\left(\mathrm{N}-\mathrm{NH}_{4}\right.$ and $\left.\mathrm{N}-\mathrm{NO}_{3}\right)$. Sampled soil layers were 0-30, 30-60 and 60-90 cm.

Maize and triticale were harvested at dough-stage (grains containing $30-35 \% \mathrm{DM}$ ) at $15 \mathrm{~cm}$ stubble height. Total $\mathrm{N}$ content of all harvested material was determined.

Data were log normal transformed and analysed using

Table 1. Treatments used in the nine-year experiment. All combinations of six crop rotation schemes (a) and four slurry treatments (b) were used, thus resulting in 24 plots per replicate. Treatments (crop rotation $x$ slurry) were fully randomised.

Crop rotation schemes, with Year 1 (Y1) being the first year of the rotation. $\mathrm{G}=$ grass/clover, being a mixture of perennial ryegrass (Lolium perenne) and white clover (Trifolium repens); $\mathrm{M}=$ maize; $\mathrm{T}=$ winter triticale. To minimise confounding with weather conditions in any year, and effects of the original grass/clover sward, Replicate 1 started in 2002 with Y4 of all sequences, Replicate 2 with Y5 and Replicate 3 with Y6.

\begin{tabular}{|c|c|c|c|c|c|c|c|c|c|}
\hline \multirow[t]{2}{*}{ Crop rotation } & \multicolumn{9}{|c|}{ Year } \\
\hline & Y1 & Y2 & Y3 & Y4 & Y5 & Y6 & Y7 & Y8 & Y9 \\
\hline G2M1 & $\mathbf{G}$ & G & $\mathbf{M}$ & $\mathbf{T}$ & $\mathrm{G}$ & $\mathrm{G}$ & $\mathrm{M}$ & $\mathrm{T}$ & $\mathrm{G}$ \\
\hline G2M2 & $\mathbf{G}$ & G & $\mathbf{M}^{1}$ & $\mathbf{M}$ & $\mathbf{T}$ & G & $\mathrm{G}$ & $M$ & M \\
\hline G3M1 & G & G & G & $\mathbf{M}$ & $\mathbf{T}$ & $\mathrm{G}$ & $\mathrm{G}$ & $\mathrm{G}$ & M \\
\hline G3M2 & G & G & $\mathbf{G}$ & $\mathbf{M}^{1}$ & $\mathbf{M}$ & $\mathbf{T}$ & $\mathrm{G}$ & $\mathrm{G}$ & $\mathrm{G}$ \\
\hline G4M1 & G & G & G & G & $\mathbf{M}$ & $\mathbf{T}$ & G & $\mathrm{G}$ & $\mathrm{G}$ \\
\hline G4M2 & G & G & G & G & $\mathbf{M}^{1}$ & M & $\mathbf{T}$ & $\mathrm{G}$ & $\mathrm{G}$ \\
\hline
\end{tabular}

${ }^{1}$ First-year maize was sown following harvest and cultivation of grass/clover in spring; when maize was grown in two consecutive years, a green manure crop (either winter rye or a rye/Italian ryegrass mix) was sown after the first year maize.

b) Slurry application strategies and the amount of $\mathrm{N}$ applied ( $\mathrm{kg}$ total $\mathrm{N} / \mathrm{ha} / \mathrm{year}$ ).

\begin{tabular}{lll}
\hline Slurry application strategy & Crop \\
& Grass/clover & Maize or triticale \\
\hline S1 & 0 & 0 \\
S2 & 0 & $120^{1}$ \\
S3 & 120 & 0 \\
S4 & 120 & $120^{1}$ \\
\hline
\end{tabular}

${ }^{1}$ For the first-year maize crop, slurry was applied in early spring, before grass/clover was harvested and cultivated. 


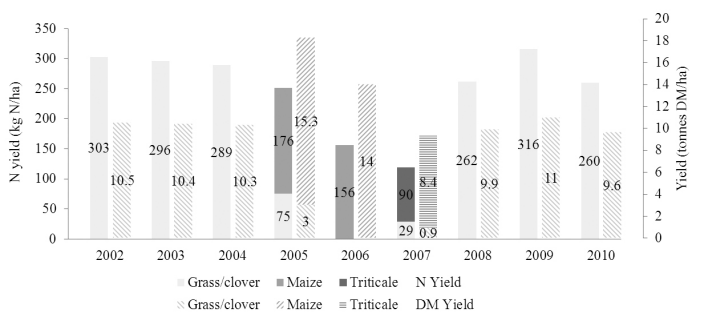

Figure 1 Annual DM yield (kg DM/ha) and $\mathrm{N}$ yield ( $\mathrm{kg} \mathrm{N} / \mathrm{ha})$ of grass/clover, maize and triticale in consecutive years in treatment G3M2S4, with 2002 being the first year of the crop rotation. Fitted values are given.

REML (Genstat 2012). The fixed model terms were crop (first-, second-, third- or fourth-year grass/clover, grass/clover before maize, first- or second-year maize, triticale, grass/clover after triticale); slurry application; vyear being the year as a variate to assess trends; for $\mathrm{DM}$ and $\mathrm{N}$ yield also harvest number of grass/clover (first to fifth cut); for soil properties also soil layer; and all interactions. Individual terms were sequentially dropped from the model when not significantly adding to variance accounted for. The resulting fixed models were used to calculate the fitted values reported. The random models consisted of replicate, calendar year, harvest number, plot number and their interactions.

Significant treatment effects $(\mathrm{P}<0.05)$ are reported on log normal scale, with the standard error (for variates) or standard error of the difference (for factors). To illustrate the effects, treatment means were calculated using the fixed models and back-transformed to enable reporting in the original units. Further details of the treatments and statistical analysis are given in De Boer et al. (2012).

\section{Results}

Grass/clover as a main crop yielded between 6.6 and 10.8 tonnes $\mathrm{DM} / \mathrm{ha} /$ year, maize yielded between 11.6 and 15.3 tonnes $\mathrm{DM} / \mathrm{ha} /$ year and triticale between 5.8 and 8.4 tonnes $\mathrm{DM} /$ ha/year. When maize was grown after grass/clover, 2-3 tonnes DM/ha of grass/clover was harvested before maize was sown. Following triticale, grass/clover was sown and resulted in 0.6 to 0.9 tonnes $\mathrm{DM} / \mathrm{ha}$ of grass/clover in the same season.

Yields, N-yields as well as soil mineral $\mathrm{N}$ levels in autumn declined significantly over time for all treatments (Table 2). This decline was least prominent when slurry was applied in each year (S4), and intermediate results were seen when slurry was applied to either grass/ clover or to maize and triticale (S3 or S2; Table 2).

When grass/clover followed maize and triticale, the annual DM yield, $\mathrm{N}$ yield and soil mineral $\mathrm{N}$ were higher for the second year grass/clover than for the first year grass/clover. Annual DM yield and $\mathrm{N}$ yields for the third and fourth years were similar to that of the first year. Soil mineral $\mathrm{N}$ in autumn was still elevated in the third year (Table 3).

While maize yielded more DM, the $\mathrm{N}$ yield was lower than for grass/clover (Figure 1), reflecting the lower $\mathrm{N}$ content of maize compared to grass/clover.

Soil mineral $\mathrm{N}$ in autumn $(0-90 \mathrm{~cm})$ was relatively low following grass/clover (below $30 \mathrm{~kg} \mathrm{~N} / \mathrm{ha}$ ) and triticale, and significantly higher following maize (40$60 \mathrm{~kg} \mathrm{~N} / \mathrm{ha}$ ). While the soil mineral $\mathrm{N}$ levels for maize were lower in the deeper soil layers (30-60 and 60-90

Table 2 Trends in time (vyear) for annual DM yield (tonnes DM/ha), annual $\mathrm{N}$ yield ( $\mathrm{kg} \mathrm{N} / \mathrm{ha}$ ) and soil mineral $\mathrm{N}$ in autumn (0-90 $\mathrm{cm} ; \mathrm{kg} \mathrm{N} / \mathrm{ha}$ ), and their interactions with slurry treatment. Effects are given on log normal scale. SE = standard error; SED $=$ standard error of the differences.

\begin{tabular}{llllll}
\hline & vyear & SE & & & \\
\hline Total yield & -0.053 & 0.019 & & & \\
Total N-yield & -0.070 & 0.021 & & & \\
Soil mineral N & -0.084 & 0.027 & & & \\
\hline vyear.Slurry treatment & S1 & S2 & S3 & S4 & SED \\
\hline Total yield & 0 & 0.009 & 0.013 & 0.021 & 0.004 \\
Total N-yield & 0 & 0.012 & 0.010 & 0.022 & 0.005 \\
Soil mineral N & 0 & 0.014 & 0.015 & 0.022 & 0.007 \\
\hline
\end{tabular}

Table 3

Effects of consecutive years of grass/clover on annual DM yield (tonnes DM/ha), annual $\mathrm{N}$ yield (kg N/ha) and soil mineral $\mathrm{N}$ in autumn $(0-90 \mathrm{~cm} ; \mathrm{kg} \mathrm{N} / \mathrm{ha})$. Effects are given on log normal scale. SE = standard error.

\begin{tabular}{|c|c|c|c|c|c|c|c|}
\hline Grass/clover year & 1st & 2nd & SE & 3rd & SE & 4th & SE \\
\hline Yield & 0 & 0.110 & 0.039 & -0.013 & 0.048 & -0.118 & 0.066 \\
\hline N-yield & 0 & 0.214 & 0.050 & 0.043 & 0.064 & -0.137 & 0.087 \\
\hline Soil mineral N & 0 & 0.252 & 0.081 & 0.214 & 0.102 & 0.100 & 0.142 \\
\hline
\end{tabular}


$\mathrm{cm}$ ), for triticale these were higher than for the top layer of $0-30 \mathrm{~cm}$ (Table 4).

There were no significant treatment effects on soil organic matter and soil organic $\mathrm{N}$, nor were there significant changes over time.

\section{Discussion}

The treatments implemented in the experiment did not maintain the yields experienced in the first year of the experiment: both DM and $\mathrm{N}$ yields decreased over time, even when the crop rotation included 4 years of grass/ clover and $120 \mathrm{~kg} \mathrm{~N} / \mathrm{ha} /$ year as slurry. Indeed the trend in time (vyear) was negative for soil mineral $\mathrm{N}$, and was not completely offset by slurry applications (Table 2), and no interaction between the trend in time and number of years of grass/clover was apparent. Treatment effects on soil organic matter and soil organic $\mathrm{N}$ were not significant, due to high variability seen in these parameters. Some factors may have inhibited growth or $\mathrm{N}$ fixation by clover, and, therefore, reduced total yield, e.g., a sub-optimal $\mathrm{pH}$, molybdenum deficiency or soil-borne pathogens. Sub-optimal $\mathrm{pH}$ was corrected at several occasions with lime applications. Low molybdenum levels were measured in grass/clover in one replicate throughout $2002(1.2 \mathrm{mg} \mathrm{Mo} / \mathrm{kg} \mathrm{DM}$ for $\mathrm{S} 1$ and $1.6 \mathrm{mg} \mathrm{Mo} / \mathrm{kg} \mathrm{DM}$ for S4). In 2009, paddocks adjacent to the experiment were sampled for nematodes, but no infestation was found.

In this experiment, grass/clover was cut and carried away from the plots. This is comparable to the management on a support block where grass/clover is mown to be ensiled and fed out elsewhere. In that case, it is likely that nutrients will need to be returned to maintain soil fertility by applying fertiliser, effluent from the milking platform or manure from wintering facilities. On a milking platform, where grass/clover is intensively grazed, $\mathrm{N}$ will be returned via excreta of the grazing animals, and in many cases also by applying effluent, resulting in a lower risk of depleting soil mineral $\mathrm{N}$ or organic $\mathrm{N}$.

Maize yielded considerably more DM than grass/ clover, increasing the total DM yield of a system including maize in the rotation. However, the residual soil mineral $\mathrm{N}$ content in autumn was higher than for grass/clover, increasing the risk of nitrate leaching in autumn and winter. Betteridge et al. (2007) indeed report much higher $\mathrm{N}$ leaching for maize than for pasture in New Zealand. In the current experiment, also in the absence of slurry application, it took two years of cropping before the soil mineral $\mathrm{N}$ levels in autumn were at or below the original level of the grass/ clover that preceded the crop. Mineralised N from a cultivated grass/clover sward could sustain two years of maize crop in the current experiment, without the need for fertiliser or slurry $\mathrm{N}$ to maintain the maize $\mathrm{DM}$ yields. Johnstone et al. (2010) reported similar results for New Zealand conditions, and concluded that in many cases no fertiliser $\mathrm{N}$ would be required in 2 years of maize following grass/clover. Annual DM yield of maize in the current experiment was much lower than reported by Johnstone et al. (2010). This was mainly due to climatic differences between The Netherlands and New Zealand, but it was also lower than Dutch conventional farms can achieve (Van Schooten et al. 2012). With the organic management practices on Aver Heino, N applied would have been lower than for conventional systems; also seed was not treated against bird predation, and no chemical weed or pest control was used. Furthermore, soil $\mathrm{pH}$ was below optimum for maize, despite the liming.

Both triticale and maize have a lower $\mathrm{N}$ content than

Table 4 Effects of crop type and soil layer (a) and their interaction (b) on soil mineral $\mathrm{N}$ in autumn (0-90 cm; kg N/ha). Effects are given on log normal scale. SED = standard error of differences.

a)

Main effects of soil layer and crop type

\begin{tabular}{llllll}
\hline & Crop & Grass/clover & Maize & Triticale & SED \\
\hline Soil layer & $0-30 \mathrm{~cm}$ & 0 & 1.062 & 0.074 & 0.113 \\
& $30-60 \mathrm{~cm}$ & -0.460 & & & \\
& $60-90 \mathrm{~cm}$ & -0.575 & & & \\
& SED & 0.185 & & & \\
\hline
\end{tabular}

b)

Interaction soil layer $\times$ crop type

\begin{tabular}{llllll}
\hline & Crop & Grass/clover & Maize & Triticale & SED \\
\hline Soil layer & $0-30 \mathrm{~cm}$ & 0 & 0 & 0 & 0 \\
& $30-60 \mathrm{~cm}$ & 0 & -0.220 & 0.533 & 0.129 \\
& $60-90 \mathrm{~cm}$ & 0 & -0.342 & 0.661 & 0.129 \\
\hline
\end{tabular}


grass/clover (Figure 1) and will result in a lower $\mathrm{N}$ intake of animals than when grass/clover is consumed. A reduction in $\mathrm{N}$ intake may decrease urinary $\mathrm{N}$ excretion and therefore the risk of $\mathrm{N}$ leaching from urine patches (Mulligan et al. 2004).

To determine the optimal crop rotation for a dairy farm, the annual feed requirements need to be taken into account, as well as the area suitable for crop rotations. In the current experiment, maximal yields were achieved with G3M2S4 and G4M2S4. An additional year in grass/clover would extend the period of time with lower nitrate leaching risk and reduced the costs of cropping and pasture renewal. Hence, when supplements with relatively low $\mathrm{N}$ content are desirable and the farm is suitable for cropping, the G4M2 combination results in high yields, relatively low cost and an elevated risk of $\mathrm{N}$ leaching loss in only 2 out of 7 years.

\section{ACKNOWLEDGEMENTS}

The authors wish to thank staff at Aver Heino for technical assistance with the experiment and J.W. van Riel for assistance with experimental design and statistical analysis. The experiment was supported by Bioconnect, the Dutch knowledge network of organic agriculture. In 2002 to 2004 the experiment was funded by the Dutch Ministry of Agriculture, Nature and Fisheries (LNV) and the Dutch Dairy Board (Productschap Zuivel, Zoetermeer). In 2005 to 2010 the experiment was funded by the Dutch Ministry of LNV. In 2012, the reporting was funded by the Dutch Ministry of Economic Affairs, Agriculture and Innovation (EL\&I).

\section{REFERENCES}

Betteridge, K.; Hoogendoorn, C.J.; Thorrold, B.S.; Costall, D.A.; Ledgard, S.F.; Park-Ng, Z.A.; Theobald, P.W. 2007. Nitrate leaching and productivity of some farming options in the Lake Taupo catchment. Proceedings of the New Zealand Grassland Association 69: 123-129.
De Boer, H.C.; van Eekeren, N.J.M.; Pinxterhuis, J.B.; Stienezen M.W.J. 2012. Optimal length of the grassclover period in crop rotations: results of a 9-year field experiment under organic conditions. Report 660 Wageningen UR Livestock Research, Lelystad, The Netherlands. 46 pp.

Di, H.J.; Cameron, K.C. 2002. Nitrate leaching in temperate agroecosystems: sources, factors and mitigating strategies. Nutrient Cycling in Agroecosystems 46: 237-256.

Genstat 2012. GenStat for Windows, Release 14.2. VSN International Ltd., Hemel Hempstead, United Kingdom.

Johnstone, P.; Parker, M.; Kaufler, G.; Arnold, N.; Pearson, A.; Mathers, D.; Wallace, D. 2010. Growing maize silage in dairy effluent paddocks for two consecutive seasons - effect on crop yield and soil nitrogen. Proceedings of the New Zealand Grassland Association 72: 117-120.

Kayser, M.; Seidel, K.; Muller, J.; Isselstein, J. 2008. The effect of grassland renovation and break up on nitrogen losses. Grassland Science in Europe 13: 123-125.

Mulligan, F.J.; Dillon, P.; Callan, J.J.; Rath, M.; O'Mara, F.P. 2004. Supplementary concentrate type affects nitrogen excretion of grazing dairy cows. Journal of Dairy Science 87: 3451-3460.

Silgram, M.; Shepherd, M.A. 1999. The effect of cultivation on soil nitrogen mineralisation. Advances in Agronomy 65: 267-311.

Van Schooten, H.; Philipsen, B.; Groten, J. 2012. Handboek snijmais (Manual of silage maize). Wageningen UR Livestock Research, Lelystad, The Netherlands. 193 pp.

Williams, I.D.; Ledgard, S.F.; Edmeades, G.O.; Densley, R.J. 2007. Comparative environmental impacts of intensive all-grass and maize silage-supplemented dairy farm systems: a review. Proceedings of the New Zealand Grassland Association 69: 137-143. 
